\title{
超硬練り貧配合コンクリートの振動締め固めによる \\ 充填性および強度について

\author{
STUDIES ON VIBRATORY COMPACTION ON EXTREMELY \\ DRY AND LEAN MIXTURES OF CONCRETE
}

阪本 好 史*

By Yoshifumi Sakamoto

\section{1.まえがき}

コンクリート 2 次製品，とくに土木用コンクリート ブロックの製造を目的として, 貧配合で, 振動締め固め を行なって即時脱型をする超硬練りコンクリートの配合 設計指針をらるために，実験的研究を行なったものであ る。

コンクリートに振動を加えて打ち込み成形をすること は, Jour. of ACI をくってみると 1933 年頃から報文が 多、。しかし，一般に普通の比較的に富配合のプラスチ ックなコンクリートに関するものが多く, 全くスランプ のない，いわゆる超硬練りコンクリートに振動を加えて 成形し, 即時脱型するものは多くはないようである。

貧配合，超硬練り，振動締め固めコンクリートについ

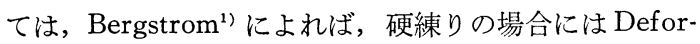
mability は振動時間が長いほど効果が大きい。この傾向 は $W / C$ が小さいほど, セメントペースト量が少ない ほど, 粗骨材量が少ないほど著しい。Cusens ${ }^{2}$ は, 型わ くの媣さが $10 \mathrm{~cm}$ 末満の場合には 3000 8000 rpm の 振動数を用うべきであり, 深い型わくの場合, dry mix や木製型わくの場合には比較的低、振動数で, 振幅の大 きい方がよく, また一般に加速度は $4 \mathrm{~g}$ 以上とすること を推奨している。振動台の振動数は, Brush ${ }^{3)}$ の例では $1260 \sim 3600$ rpm, ACI Committee 6094) ではコンクリ 一トのブロック用として 1800 7200 rpm とし，低回 転時の振幅 $1.6 \sim 3.2 \mathrm{~mm}$, 高回転時には $1.3 \mathrm{~mm}$ とい う值を示している。山田 ${ }^{5}$ によると欧州における即時脱 型の実験で, 振動数 3000 7500 rpm, 振 幅 $3 \mathrm{~mm}$ 程 度の例を揭げている。Washa $\left.{ }^{6}\right)$ にれれば, ブロック用と して振動数 $6500 \mathrm{rpm}$, 振幅 $0.8 \sim 1.0 \mathrm{~mm}$ を採用し， 振動と同時に加圧する場合には 700 900 kg を 2 4 秒 加えて, 振動数は $1800 \sim 7200 \mathrm{rpm}$ 程度としている。

Green $^{7)}$ は, 振動数 2 100 14 $700 \mathrm{rpm}$ の範囲で加速度 を変化させて実験を行ない, 単粒骨材の配合では, 最適 の振動数核骨材粒径の影響を受けて, 粒径が増すほど大 きくなる傾向があること, 最適の振動数を加えた場合の 強度は, 平均強度より 6 30\% 大きく, 最適振動数より

$*$ 正会員 八㽑化学工業 (株) 研究員
少し高い振動数によって, しばしば強度は著しく低下す ること,また強度には速度とか振幅よりも, どの振動数 においても加速度が影響して, 加速度が増すと強度も増 すと説明している。つぎに配合の関係では, 内山文によ れば, 圧縮強度からみた場合に, 単位セメント量が 250 $\mathrm{kg} / \mathrm{m}^{3}$ で, 振動打込みの時の最小の単位水量は約 $90 \mathrm{~kg}$ / $\mathrm{m}^{3}$ であるという。石橋・四戸・有川 ${ }^{9}$ は粗骨材最大寸法 を $20 \mathrm{~mm}$ を限度としている。Kreman ${ }^{10)}$ によると， L'Hermite は粒径区分によって励起振動数を次式で示し ている。

$$
d<14 \cdot 10^{6} / n^{2}
$$

ただし，

$d:$ 粒子径 $(\mathrm{mm})$

$n:$ 振動数 $\left(\mathrm{min}^{-1}\right)$

ACI Committee 211 11 ) では, No-Slump Concrete の 必要水量や粗骨材量の概略值を与えている。山本・相沢 ・伊福部 ${ }^{12)}$ は, 振動数 $9000 \mathrm{rpm}$ のブロック成形機によ る実験から, 空げき率が $1 \%$ 増すと, 強度は約 $6 \%$ 減少 すること, 空げき率の許容限度は 8～9\% であること， 一般に $W / C$ の増加にしたがって強度は増加すること, また単位セメント量は $225 \mathrm{~kg} / \mathrm{m}^{3}$ 以上が望ましく, 貧配 合のときは $s / a, W / C$ の影響が大きいなどの結果をえて いる。

振動台については, 実験では Vertical linear vibration および Vertical circular vibration のものが多く 使用されており，時には外部振動機を数台とりつけたも のもあって，振動の特性はあまり明確でない。

以上のように従来の報文では，各人各様の結果を得て おり，一貫した説明を求めることはむずかしい。

本報では, 振動数 $3000 \sim 7800 \mathrm{rpm}$, 振幅 $0.2 \sim 0.6$ $\mathrm{mm}$ の範囲で成形する場合の, コンクリートの充填率お よび圧縮強度におよぼす粗骨材最大寸法, 砂の粗粓率, 単位水量, 単位セメント量などの配合上のふくそうする 要因機構の総合的影響を, 多变量解析方法として重相関 分析方法 ${ }^{13)}$ にっって統計的に解析し, 各要因の相関 係，有意性などについて検定した結果に基づいて，貧配 合超硬練りコンクリートの配合基準と, 条件の異なる場 合の補正方法を提案したものである。 


\section{2. 使用材料，装置および試験作業方法}

(1) 使用材料

(1) セメント：B種高炉セメントを用いた。

(2) 細 骨 材: 福岡県遠賀川産, 性状は図一1, 表一1 に示す。

(3) 粗 骨 材: 高知県桂浜産の砂利, お子よび福岡県門 司産砕石, 性状は 図一1, 表一1 に示 す。

（4) 水 : 水道水を用いた。

図一1 骨材の粒度分布

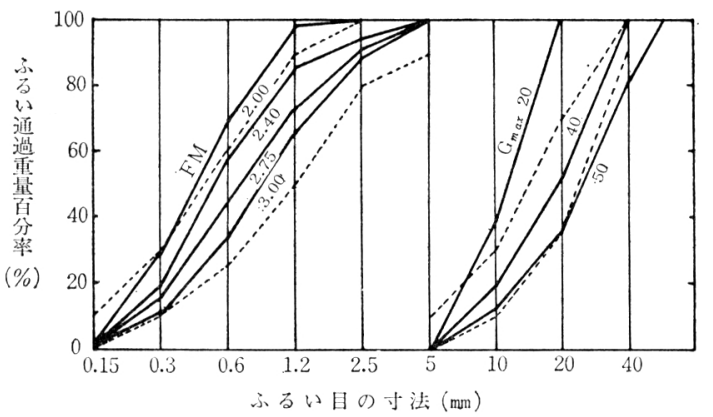

表一1 骨材の性 状

\begin{tabular}{|c|c|c|c|c|c|}
\hline \multirow{2}{*}{ 骨材の種別 } & \multirow{2}{*}{ 比 重 } & \multirow{2}{*}{$\begin{array}{c}\text { 吸水量 } \\
(\%)\end{array}$} & \multirow{2}{*}{$\begin{array}{l}\text { 洗 W } \\
(\%)\end{array}$} & \multicolumn{2}{|c|}{$\begin{array}{c}\text { 単位容積重量 } \\
\left(\mathrm{kg} / \mathrm{m}^{3}\right)\end{array}$} \\
\hline & & & & 軽 盛 & 標 準 \\
\hline 砂 利 $50 \mathrm{~mm}$ & 2.68 & - & - & - & - \\
\hline$" 40 "$ & 2.68 & 1.15 & 2.0 & 1770 & 1870 \\
\hline " $20 "$ & 2.68 & - & - & 1730 & 1890 \\
\hline 砕 石 40 ” & 2.72 & 0.60 & 0.1 & 1590 & 1620 \\
\hline 砂 FM 3.00 & 2.57 & 1.62 & 0.7 & 1520 & 1640 \\
\hline " 2.75 & 2.57 & - & - & 1530 & 1640 \\
\hline " 2.40 & 2.57 & - & - & 1480 & 1600 \\
\hline " 2.00 & 2.57 & - & - & 1440 & 1570 \\
\hline
\end{tabular}

\section{（2）振 動 台}

振動台 $(450 \times 450 \mathrm{~mm})$ は, 振動数 $1800 \sim 7800 \mathrm{rpm}$, 振幅 $0.0 \sim 1.0 \mathrm{~mm}$ の範囲で連続可変のものを作製した (写真一1)。遠心力は公称 $500 \mathrm{~kg}$ である。振動はテーブ ル上わくの下で偏心質量を回転させて強制振動を起こさ せるものであるが，テーブル上わくは硬質の防振ゴムで

\section{写真一1 実験用振動台}

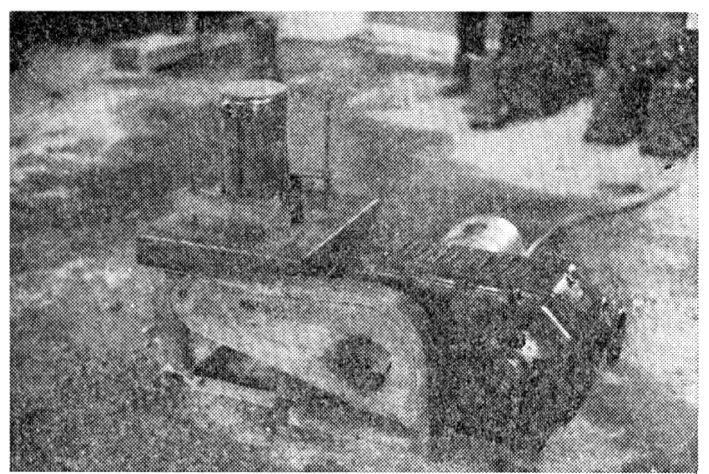

図一2 振動の記録

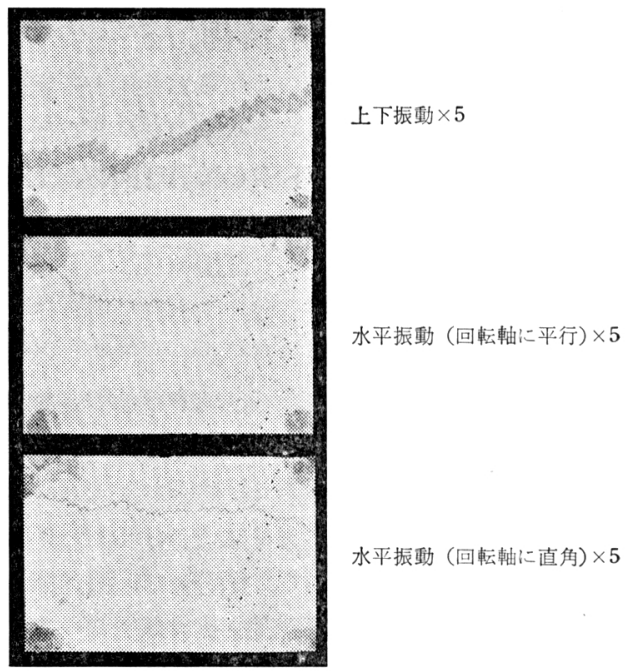

支持され，水平動に 対しては, 不完全で はあるが拘束する構 造にしてあるので， 図一2にその測定例 を示すように, 主と して上下方向に振動 する。振動数および 振幅は手持ち振動 計 $^{14)}$ (写真一2)によ って, コンクリート を充填して振動締め 固めをしている型 わくの上部の振動 を測定した。振動 の波形について は, 写真一 3 に示 すよらにオシロス コープによって観 察した結果, 比較 的ひずみのない正 弦波形であること を認めた。
写真-2 手持振動計

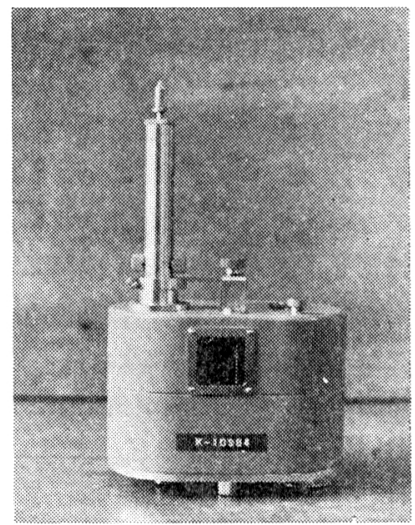

写真一3 上下振動波形の例

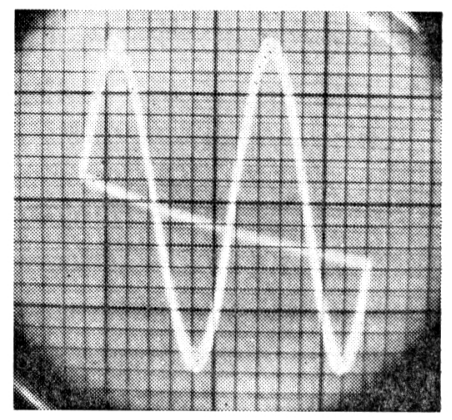

(3) 試験作業方法

a）練りまぜおよび成形の標準作業方法

予備試験によって，つぎの作業方法を標準とした。

(1)ミキサに計量した材料を同時に投入して，3 分間 練りまぜる(ミキ正は 2 切可傾式を用い，1 バッチは 20 し程度とした)。

(2)ミキサからコンクリートを受け皿に排出して，シ ョベルで均一になるよらに練りまぜる。

(3) 振動台に固定した, 重量を測定した型わく（ $\phi 15$ 
$\times 30 \mathrm{~cm})$ に，ほぼ一杯になるようにコンクリートを軽 く詰める。

(4) 振動を加え始めると, コンクリートは沈下するの で，その分だけコンクリートを手で補充する。

(5) 所定の振動時間に達する5 秒前にコンクリートを 型わくの上面に約 $3 \mathrm{~cm}$ ほど軽く手で盛り上げておい て，上から木板を当てて，手で押えた状態で定時に振動 台を停止する。

(6) コンクリートの上面を木鏝でならす。

(7) 振動台からとりはずして, 型わくごと重量を測定 する。

(8)ただちに側面の型わくだけをを静かにとりはずす。

b）養生方法

脱型した供試体は, 所定の位置 (この実験はすべて実 験室内）に翌日まで静置する。材令 1 日にセメントペ ーストでキャッピングを施し, 同じ位置に試験材令ま で，空中に露出したままとする。

c) 供試体の充填率の求め方

振動成形をしたコンクリートの充填率は次式のように して求めた。 充填率 (\%)

$$
\begin{aligned}
& \text { 二 } \frac{\text { コンクリートと型わくの重量一型わくの重量 }}{\text { 配からきる型わくの中のコンクリート理論重量 }} \\
& \quad \times 100
\end{aligned}
$$

供試体は原則として 2 個ずっ成形して, その平均值を求 めた。

\section{3. 実験の方法}

この実験では一般にコンクリートの成形は上述の標準 作業方法にしたがい, 実験結果の判定には成形した供試 体の充填率と圧縮強度について検討を加えた。

（1）成形条件と締め固めたコンクリートの性質につ いて

a) 振動数，振幅および加速度の影響

振動数と振幅を変化させて，2 分間振動を加えて成形 する。砂は粗粒率が 2.75 のもの, 砂利は最大寸法が 50 , 40,20 mm のものを用いた。コンクリートの配合は表一 2 に示す通りである。

\begin{tabular}{|c|c|c|c|c|c|c|c|c|}
\hline \multirow{2}{*}{$\begin{array}{l}\text { 配 合 } \\
\text { 記 号 }\end{array}$} & \multirow{2}{*}{$\begin{array}{c}\text { 粗 晨材 } \\
\text { 最大寸法 } \\
(\mathrm{mm})\end{array}$} & \multirow{2}{*}{$\begin{array}{l}s / a \\
(\%)\end{array}$} & \multirow{2}{*}{$\begin{array}{l}W / C \\
(\%)\end{array}$} & \multicolumn{3}{|c|}{ 単 位 量 } & \multicolumn{2}{|c|}{$\left(\mathrm{kg} / \mathrm{m}^{3}\right)$} \\
\hline & & & & $W$ & $C$ & $S$ & $G$ & 計 \\
\hline A & 20 & 40 & 55.0 & 110 & 200 & 848 & 1299 & 2457 \\
\hline B & 40 & 40 & 52.5 & 105 & 200 & 853 & 1317 & 2475 \\
\hline $\mathrm{C}$ & 50 & 30 & 45.0 & 90 & 200 & 650 & 1566 & 2506 \\
\hline
\end{tabular}

\section{表一2 コンクリート配合表}

\section{b）振動時間の影響}

単位セメント量 $200 \mathrm{~kg} / \mathrm{m}^{3}$, 粗骨材最大寸法 $40 \mathrm{~mm}$, 砂の粗粒率 $1.93 \sim 2.81$, 細骨材率 $30 \sim 60 \%$, 単位水量 $85 \sim 140 \mathrm{~kg} / \mathrm{m}^{3}$ のコンクリートに振動数 $7200 \mathrm{rpm}$, 振
幅 $0.6 \mathrm{~mm}$ の振動を 30 秒〜 6 分加えて成形する。実験 はこの範囲の条件の組合わせ 40 種類について行なった。

c）振動成形時のコンクリートの状況

貧配合の超硬練りコンクリートを振動成形するような 場合に, 型わく中のコンクリートが流動するように変位 することが観察される。これは同じコンクリートをVee Bee 試験機で振動した場合にも同様である。そこで型わ く内のコンクリートの内部においても運動していること を予想して，どのような変位をするものかを調べて，製 品の均質化と, 表面の仕上りを改善するために参考にす るものである。実験は振動を受けているコンクリートの どの部分がどの程度の移動をしているかを知るために, 供試体を作る際に高さ $6 \mathrm{~cm}$ ごとの 5 層に別けて, 各層 の境界に白色セメントで水平に縞を作っておいて振動を 加えた。一定の配合のコンクリートに一定の振動を加え て, 30 秒, $1,2,3,6$ 分したら脱型して, 表面に出た縞 模様の乱れ方, および供試体を切断した切り口を観察す ることによって, 振動時間と中のコンクリートの変位の 状況を知ることができる。振動時間が長くなると，コン クリートの変位する量も大きくなり，層が逆転すること も起こるので縞を層別に着色して区別した。

\section{（2）配合条件と締め固めたコンクリートの性質につ いて}

配合上のいろいろな要因が, 締め固めたコンクリート の性質におよぼす影響を調べるもので, つぎのような配 合の条件を組み合わせて, 212 種類のコンクリートにつ いて, 振動数 $7200 \mathrm{rpm}$, 振幅 $0.6 \mathrm{~mm}$, 振動時間 2 分間 として成形する。
単位セメント量 $\left(\mathrm{kg} / \mathrm{m}^{3}\right) \quad 200,220,250,280$
粗骨材最大寸法 (mm) $50,40,20$

細 骨 材 率 (\%) $25,30,40,50$

単 位 水 量 即時脱型することができて, 振 動により多量のペーストが流出し たり，外観上不適当な豆板を生じ なく, 脱型後に沈下変形をしない 範囲に定める。

（3）砕石を使用する場合について

現場では砕石を使用する場合もあるので，砂利に対比 して砕石の場合について調べるものである。振動締め固 めの方法などは砂利の時と全く同様にして，

i ) 単位水量 $110 \mathrm{~kg} / \mathrm{m}^{3}$, 単位セメント量 $200 \mathrm{~kg} / \mathrm{m}^{3}$, 細骨材率 $40 \%$ の配合とし, 振動数 $7200 \mathrm{rpm}$, 振 幅 $0.6 \mathrm{~mm}$ の振動を 30 秒, $1,2,3,6,12$ 分間加え て成形する。

ii）表一8 に示すような配合とし, 振動数 $7200 \mathrm{rpm}$, 振幅 $0.6 \mathrm{~mm}$, 振動時間 2 分間で成形する。

\section{（4）混和剂の影響について}

貧配合, 超硬練りコンクリートの振動締め固めに対す 
る混和剂の影響を調べるものである。細骨材の粗粒率 2.75 , 粗骨材最大寸法 $20 \mathrm{~mm}$ の砂利, および混和剤に は分散剂 P (リグニンスルホン酸カルシウム), $\mathrm{AE}$ 剂 $\mathrm{V}$ (変性アビェチン酸塩)を使用した。この実験には, 材料混合の方法 $\mathrm{A}_{1}, \mathrm{~A}_{2}$, 配合の種類を $\mathrm{B}_{1}, \mathrm{~B}_{2}$, 混和剤の 種類による効果を $\mathrm{C}_{1}, \mathrm{C}_{2}, \mathrm{C}_{3}$ とした三元配置法によっ た。

\section{i ）材料混合の方法}

超硬練りで，筫配合の場合にはコンクリート中のペー スト量が少なくて，プラスチックなコンクリートのよう に練りまぜができないので，つぎのような 2 通りの方法 について比較した。

$\mathrm{A}_{1}$ : 練りまぜ方法は, 従来の普通コンクリートの場合 と同様に，セメント，砂，砂利および規定量の混和剤を 水に溶解した混合水を同時にミキサに投入して，3 分間 混合する。

$\mathrm{A}_{2}$ : 最初にセメントと規定量の混和剤を溶解した混合 水を 2 分間練りまぜてペーストを作り，つぎに砂と砂利 を投入して 3 分間練りまぜる。

\section{ii）配合の種類}

配合は，その貧富による混和剤の効果の差を知るため に，単位セメント量を $200,250 \mathrm{~kg} / \mathrm{m}^{3}$ とし，それぞれ 充填率が約 $99 \%$ になる水量を定めた。すなわち配合は つぎのとおりとした。

\begin{tabular}{clll} 
配合種別 & \multicolumn{1}{c}{ セメント } & 水 & 細骨材率 \\
$\mathrm{B}_{1}$ & $200\left(\mathrm{~kg} / \mathrm{m}^{3}\right)$ & $110\left(\mathrm{~kg} / \mathrm{m}^{3}\right)$ & $40(\%)$ \\
$\mathrm{B}_{2}$ & 250 & 100 & 40
\end{tabular}

iii）混和剤の種類

混和剤には分散剤， $\mathrm{AE}$ 剂を 1 種類ずつ選び，つぎの 3 水準とした。

$$
\begin{aligned}
& \mathrm{C}_{1}: \text { プレーン } \\
& \mathrm{C}_{2}: \text { 分散剤 } \mathrm{P} \text { (セメント量の } 0.5 \% \text { 使用) } \\
& \mathrm{C}_{3}: \mathrm{AE} \text { 㓮 } \mathrm{V} \text { (セメント量の } 0.04 \% \text { 使用) }
\end{aligned}
$$

成形および養生方法は標準作業方法により，振 動数 $7200 \mathrm{rpm}$, 振幅 $0.6 \mathrm{~mm}, 2$ 分間振動を加えた。

\section{（5） 長期強度について}

以上の実験は, 主として製造工程中の運搬時の所要強 度から, 材令 $3 \sim 4$ 日の強度について検討するものであ る。この実験ではそのようなコンクリートの長期間後に 発現する強度を調べる。砂の粗粒率 2.75 , 砂利の最大寸 法 $40 \mathrm{~mm}$, 混和剂は分散剂 $\mathrm{P}$ および $\mathrm{AE}$ 剂 $\mathrm{V}$ を使用し た。コンクリートの配合は 表一15 に示す通りである。 締め固めは振動数 $7200 \mathrm{rpm}$, 振幅 $0.6 \mathrm{~mm}$, 振動時間 2 分間とした。養生方法は材令 2 日までは $20^{\circ} \mathrm{C}$ 室内, 以 後強度試験日まで $20^{\circ} \mathrm{C}$ 水中に養生した。

記 号

$$
\begin{aligned}
& n: \text { 振動数 }(\mathrm{rpm}) \\
& b: \text { 全振幅 }(\mathrm{mm})
\end{aligned}
$$

\section{$k:$ 加速度 $(\mathrm{g})$ \\ $t:$ 振動時間 (分) \\ $\xi$ : 充填率 (\%)}

$\sigma_{28}$ : 圧縮強度 $\left(\mathrm{kg} / \mathrm{cm}^{2}\right)$, 添字は材令 (日)

$G_{\max }$ : 粗骨材最大寸法 $(\mathrm{mm})$

$F M:$ 砂の粗粒率

$F M_{(A)}$ : 砂利, 砂混合物の粗粒率

$$
\begin{aligned}
s / a & : \text { 細骨材率 }(\%) \\
W & : \text { 単位水量 }\left(\mathrm{kg} / \mathrm{m}^{3}\right) \\
C & : \text { 単位セメント量 }\left(\mathrm{kg} / \mathrm{m}^{3}\right) \\
p & : \text { セメント ペースト量 }\left(l / \mathrm{m}^{3}\right) \\
a & : \text { 全骨材量 }\left(l / \mathrm{m}^{3}\right)
\end{aligned}
$$

\section{4. 実験結果と考察}

\section{（1）成形条件と締め固めたコンクリートの性質}

a) 振動数，振幅および加速度の影響

実験の結果は 表一3に示す通りである。この結果から 成形した供試体の充填率または材令 3 日圧縮強度に対す る, 振動数, 振幅, 加速度, 粗骨材最大寸法, 単位水 量，細骨材率などの重相関関係を明らかにした。計算は 電子計算機 NEA C 2200 により, 解析の結果は表一4 にその例を示す通りである。圧縮強度への各要因の効果 と，充填率への効果はよく似た傾向が認められた。すな わち

i ） 充填率と強度はここにとりあげた要因によって， 重相関係数, 回帰䛊差（標準偏差で表わしてある）, 寄

\begin{tabular}{|c|c|c|c|c|c|c|c|c|}
\hline \multirow{2}{*}{$\begin{array}{l}\text { 振 動 数 } \\
\text { (r.p.m.) }\end{array}$} & \multirow{2}{*}{$\begin{array}{l}\text { 振 幅 } \\
(\mathrm{mm})\end{array}$} & \multirow{2}{*}{$\begin{array}{c}\text { 加速度 } \\
(\mathrm{g})\end{array}$} & \multicolumn{3}{|c|}{ 充 填 率 (\%) } & \multicolumn{3}{|c|}{$\begin{array}{c}\text { 日压縮玧度 } \\
\left(\mathrm{kg} / \mathrm{cm}^{2}\right)\end{array}$} \\
\hline & & & 配合 $\mathrm{A}$ & 配合 B & 配合 C & 配合A & 配合 B & 配合C \\
\hline 6780 & 0.6 & 15.4 & 100 & 98 & 100 & 124 & 110 & 152 \\
\hline 5340 & 0.6 & 9.6 & 99 & 97 & 99 & 124 & 99 & 145 \\
\hline 7120 & 0.5 & 14.1 & 100 & 98 & 100 & 129 & 103 & 155 \\
\hline 5340 & 0.5 & 8.6 & 98 & 98 & 99 & 109 & 104 & 153 \\
\hline 7260 & 0.4 & 11.8 & 98 & 98 & 99 & 118 & 91 & 160 \\
\hline 5350 & 0.4 & 6.3 & 96 & 97 & 98 & 107 & 87 & 150 \\
\hline 3590 & 0.4 & 2.9 & 95 & 96 & 98 & 73 & 79 & 140 \\
\hline 7050 & 0.3 & 8.5 & 97 & 98 & 99 & 92 & 115 & 162 \\
\hline 5225 & 0.3 & 4.3 & 96 & 96 & 97 & 91 & 98 & 126 \\
\hline 3900 & 0.3 & 2.6 & 95 & 96 & 98 & 93 & 97 & 137 \\
\hline 6840 & 0.2 & 5.2 & 95 & 96 & 98 & 72 & 95 & 144 \\
\hline 5100 & 0.2 & 2.3 & 93 & 92 & 96 & 56 & 69 & 119 \\
\hline 4150 & 0.2 & 2.1 & 92 & 91 & 96 & 48 & 51 & 117 \\
\hline
\end{tabular}
与率などの值から 相当に高い相関を 得ることがわかる。

ii）充填率, 強度に関しては, 振動数と振幅を要因 と考える方が，加速度を要因とするよりも，やや精度よ く推定することができる。

iii）充填率と強度は, 振動数, 振 幅, 粗骨材最大寸 法, 細骨材率の 4 要因のうち, 振動数, 振幅, 細骨材率 の 3 要因でも，また加速度と細骨材率の 2 要因からも精 度よく推定できる。

表一3 測 定 結 果 
表一4（Y）充填率 (\%) と（1）振動数 (rpm)，（2）振幅 (mm)，(3) 加速度 (g),

(4) 粗骨材最大寸法 $(\mathbf{m m})$, (5) 単位水量 $(\mathbf{k g})$, (6) 細骨材率 (\%) との関係

\begin{tabular}{|c|c|c|c|c|c|c|c|c|c|c|}
\hline \multirow{2}{*}{ 変数の項目 } & \multirow{2}{*}{ 相関係数 } & \multicolumn{3}{|c|}{ 回 } & \multicolumn{3}{|c|}{ 数 } & \multirow{2}{*}{ 回㷌誤差 } & \multirow{2}{*}{ 寄与率 } & \multirow{2}{*}{ 偏 相 関 係 数 } \\
\hline & & $\mathrm{B}_{1}$ & $\mathrm{~B}_{2}$ & $\mathrm{~B}_{3}$ & $\mathrm{~B}_{4}$ & $\mathrm{~B}_{5}$ & $\mathrm{~B}_{6}$ & & & \\
\hline Y 1246 & $0.898^{* *}$ & $\begin{array}{l}\times 10^{-2} \\
0.063\end{array}$ & 9.7 & & -0.004 & & -0.192 & 1.000 & 0.78 & $r_{x 1 y \cdot x 2 x 4 x 6=0.626}{ }^{* *}$ \\
\hline Y 3456 & $0.845^{* *}$ & & & 0.28 & 0.143 & 0.886 & -1.429 & 1.667 & & $r_{x 2 y \cdot x 1 x 4 x 6=0.810^{* *}}$ \\
\hline Y 124 & $0.819^{* *}$ & 0.063 & 9.7 & & 0.044 & & & 1.288 & & $r_{x 3 y \cdot x 4 x 5 x 6=0.772^{* *}}$ \\
\hline Y 126 & $0.898^{* *}$ & 0.063 & 9.7 & & & & -0.188 & 0.987 & 0.73 & $r_{x 4 y \cdot x 1 \times 2 x 6=-0.034}$ \\
\hline Y 146 & $0.661^{* *}$ & 0.088 & & & -0.004 & & -0.192 & 1.682 & & $r_{x 4 y} \cdot x 3 \times 4 x 5=0.067$ \\
\hline Y 246 & $0.826^{* *}$ & & 11.1 & & -0.004 & & -0.192 & 1.264 & & $r_{x 5 y \cdot x 3 x 4 x 6=0.664^{* *}}$ \\
\hline Y 345 & $0.854^{* *}$ & & & 0.36 & -0.036 & -0.128 & & 1.166 & & $r_{x 6 y \cdot x 1 \times 2 x 4=0.644}{ }^{* *}$ \\
\hline Y 346 & $0.854^{* *}$ & & & 0.36 & -0.004 & & -0.192 & 1.166 & 0.71 & $r_{x 6 y} \cdot x 3 \times 4 \times 5=-0.008$ \\
\hline Y 356 & $0.854^{* *}$ & & & 0.36 & & 0.017 & -0.218 & 1.166 & 0.71 & \\
\hline Y 456 & $0.378^{* *}$ & & & & 0.143 & 0.914 & -1.571 & 2.113 & & \\
\hline Y 12 & $0.795^{* *}$ & 0.063 & 9.7 & & & & & 1.342 & 0.61 & \\
\hline Y 14 & $0.548^{* *}$ & 0.088 & & & 0.044 & & & 1.849 & & \\
\hline Y 16 & $0.661^{* *}$ & 0.088 & & & & & -0.188 & 1.659 & & \\
\hline Y 24 & $0.739^{* *}$ & & 11.1 & & 0.044 & & & 1.491 & & \\
\hline Y 26 & $0.826^{* *}$ & & 11.1 & & & & -0.188 & 1.250 & 0.64 & \\
\hline Y 34 & $0.770^{* *}$ & & & 0.36 & 0.044 & & & 1.410 & & \\
\hline Y 35 & $0.846^{* *}$ & & & 0.36 & & -0.100 & & 1.177 & 0.70 & \\
\hline Y 36 & $0.854^{* *}$ & & & 0.36 & & & -0.188 & 1.150 & 0.71 & \\
\hline Y 45 & $0.418^{*}$ & & & & -0.036 & -0.128 & & 2.008 & & \\
\hline Y 46 & $0.418^{*}$ & & & & -0.004 & & -0.192 & 2.008 & & \\
\hline Y 56 & $0.418^{*}$ & & & & & 0.017 & -0.218 & 2.008 & & \\
\hline Y 1 & $0.512^{* *}$ & 0.088 & & & & & & 2.103 & & \\
\hline Y 2 & $0.712^{* *}$ & & 10.4 & & & & & 1.531 & & \\
\hline Y 3 & $0.745^{* *}$ & & & 0.36 & & & & 1.455 & & \\
\hline Y 4 & 0.196 & & & & 0.044 & & & 2.138 & & \\
\hline Y 5 & -0.402 & & & & & -1.005 & & 1.997 & & \\
\hline Y 6 & $-0.418^{* *}$ & & & & & & -0.188 & 1.981 & & \\
\hline
\end{tabular}

*危険率 $5 \%$ で有意 ** 同 $1 \%$ で有意

図一3 振動数と充填率との関係

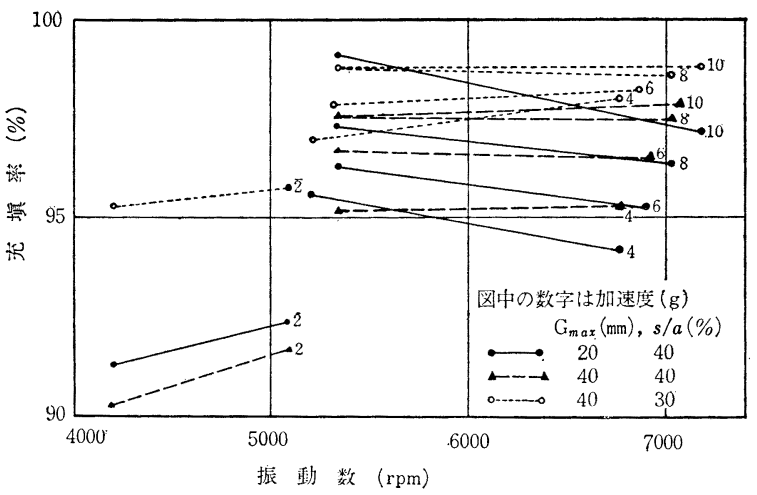

iv）充填率と強度に対して，振幅の方が 振動数より 相関が高い。

v）振動数, 振幅あるいは加速度が 増すと充填率お よび強度は大となる（図一3）。

vi）粗骨材最大寸法は，充填率や強度に対して，偏 回帰係数が正または負の值をとり，絶対值も小さく，偏 相関係数も小さいことから，他の要因の影響よりも小さ いと考えられる。

vii） 充填率と強度に対しては，細骨材率は負相関を 示す。

viii）寄与率の大きい要因に対する重回帰式を推定す ると，

$$
\begin{aligned}
& \xi=0.00063 n+9.7 b-0.004 G_{\max }-0.19 s / a+97 \\
& \sigma_{3}=0.0067 n+81.5 b-0.15 G_{\max }-5.09 s / a+233
\end{aligned}
$$
のように表わされる。すなわち $n, b$ が増すと $\xi, \sigma_{3}$ は 増し, $G_{\max }, s / a$ が増すと $\xi, \sigma_{3}$ は減少する。

b）振動時間の影響

実験結果に対して, 振動時間, 単位水量, 細骨材率 を要因として, 充填率および圧縮強度に関して, 前と 同様な方法で重相関分析を行なった。すなわち，これ らを要因と考える時, 重相関係数 0.95 , 寄与率 0.88 と高い相関が得られ，重回帰式はつぎのように推定さ れる。

$$
\begin{aligned}
& \xi=0.62 t+0.262 W-0.69 s / a+91 \\
& \sigma_{4}=3.9 t+0.147 W-3.58 s / a+198
\end{aligned}
$$

上式や偏相関係数などから，振動時間，単位水量が増す と充填率および強度は増し, 細骨材率が増すと充填率, 強度は減ずる傾向が認められる。

c）振動成形時のコンクリートの状況

コンクリートの状態は 写真-4 4 5 の例に示すように 移動していることがわかる。コンクリートの移動には, 振動台の特性, 型わくの形や寸法などの影響が大きいと 考えられる。この実験に用いた振動台のように偏心鍾が 1 組のものは，水平方向の拘束度が低いと不整な運動を する。そして中のコンクリートは流れを生じながら締め 固まる。したがって供試体の部分によって締め固まりの 
写真一4振動によるコンクリートの移動状況（外観）

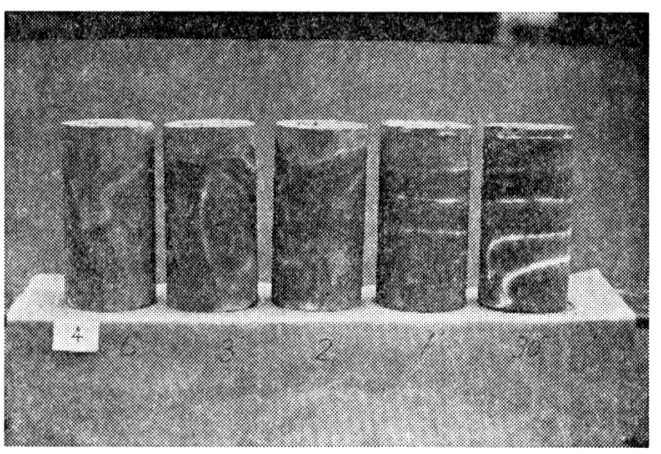

写真一5 振動によるコンクリートの移動状況（断面）

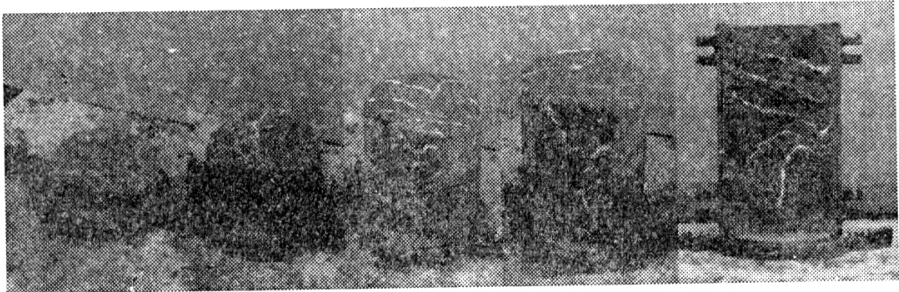

の移動量も大きく, 乱れも著しく, 振動時間が長くなる と縞が広がって不明瞭となっている。

\section{（2）配合条件と締め固めたコンクリートの性質}

配合上の各種の要因が怙よぼす効果を調べたものであ る。解析は各種の要因の組み合わせ 212 組の実測值から 106 組をランダムに選び, 重相関分析を行なった。この

表一5 実 験 結 果

\begin{tabular}{l|r|r|r|c}
\hline & 平均值 & 標準偏差 & 最大值 & 最小 值 \\
\hline 単位 水量 $\left(\mathrm{kg} / \mathrm{m}^{3}\right)$ & 106 & 17.5 & 130 & 85 \\
充填率 $(\%)$ & 97 & 3.8 & 100 & 89 \\
4 日厌縮強度 $\left(\mathrm{kg} / \mathrm{cm}^{2}\right)$ & 148 & 49.2 & 254 & 32 \\
\hline
\end{tabular}

106 組のデータにおける主な数值は 表一5 の通りである。

a) 充填率と各種要因との関係

(1) 充填率と粗骨材最大寸法, 砂の粗粒 率, 細骨材率, 単位水量, 単位セメント量 との関係

これらの要因についての解析の結果は表 -6 に示亦通りである。偏相関係数の検定
程度にムラを生じるこになる。この実験によって，成 形に際して, 供試体の部分によって美しく仕上った所 と, あらあらしい豆板のようになる所があるが, 全体を 美しく仕上げるためには，コンクリートの配合条件によ って改善できるものか, 成形あるい:脱型の方法, また は型わくの改造などで考虑されなければならないものか の判別に役立った。

この実験による成形では, 最も締め固まりの不十分な 箇所は, モーターに近い側の下から $1 / 4$ の高さの所, お よびモーターから遠い側の上から $1 / 4$ の高さの所であっ た。この部分は外観はあらあらしくて, その原因は振動 によってコンクリートが移動してきて, その流れが型わ くによって妨げられて, 流れの向きが上または下の方向 へ転向させられる場所に当たるためであろら。またコン クリートが水平に回転する ように移動する場合もある が,この時には，午の方向 に豆板の位圆も片寄ってで きる。また供試体の横断面 をみても乱れを生じてい る。コンクリートの移動量 は型わくに近い部分が，中 心部より著しく大きい。し たがって表面に豆板ができ ていても，内部はよく締っ ており，豆板部分の深さは 大して深いものではない。 また豆板となる部分は，他 の部分よりもコンクリート
の結果から,どの要因も充填率に詨して著しく有意であ るといえる。重相関係数も大きいので, 重回帰式を推定 するとつぎのようになる。

$$
\begin{aligned}
\xi= & 0.07 G_{\max }+4.3 F M-0.39 s / a+0.223 W \\
& +0.02 C+69
\end{aligned}
$$

すなわち, $G_{\max }, F M, W, C$ が增すと $\xi$ は増し, $s / a$ が 增すと $\xi$ は減る。また同じデータによって, 粗骨材最大 寸法別に分析を行ならと, 表一6 の備考に示すよ5に, 充填率に対する重相関係数は前回よりも大きく, 回帰誤 差は小さい值を得ている。このことから充填率の推定に は, 粗骨材寸法別に行なら方が精度がよいと考えられ る。またここによりあげた要因の中では, 単位セメン ト量の効果が最も小さく, 要因としてとりあげなくても ほとんど同じ精度で充填率を推定しうることがわかる。

\begin{tabular}{|c|c|c|c|c|c|c|c|c|}
\hline & 項 目 & 単相関係数 & 偏相関係数 & 偏回帰係数 & \multicolumn{2}{|c|}{ 備 } & \multicolumn{2}{|l|}{ 考 } \\
\hline \multirow{6}{*}{$\begin{array}{l}\text { 充 } \\
\text { 填 } \\
\text { 率 } \\
\text { 之 } \\
\text { の } \\
\text { 関 } \\
\text { 係 }\end{array}$} & $G_{\max }$ & 0.140 & $0.359^{* *}$ & 0.073 & $\begin{array}{l}5 \text { 要因の㭙の } \\
\text { 重相関係数 }\end{array}$ & \multicolumn{3}{|c|}{$\begin{array}{l}G_{\max } \text { ことに層別した時 } \\
G_{\max } \text { 重相関係数 回帰誤差 }\end{array}$} \\
\hline & \multirow[t]{2}{*}{$F M$} & \multirow[t]{2}{*}{0.133} & \multirow[t]{2}{*}{$0.533^{* *}$} & \multirow[t]{2}{*}{4.250} & $0.72^{* *}$ & 50 & $0.78^{* *}$ & 0.8 \\
\hline & & & & & \multirow[t]{2}{*}{ 笴 与 率 } & 20 & $0.82^{* * *}$ & 1.7 \\
\hline & $s / a$ & -0.114 & $-0.670^{* *}$ & -0.386 & & \multicolumn{3}{|c|}{ 要因から C 在除いた時 } \\
\hline & $W$ & 0.175 & $0.690^{* *}$ & 0.223 & \multirow{2}{*}{$\begin{array}{c}\text { 回 㷌歌 差 } \\
2.00\end{array}$} & $G_{\max }$ & 重相関係数 & 回帰部差 \\
\hline & $C$ & 0.100 & $0.258^{* *}$ & 0.023 & & $\begin{array}{l}50 \\
40 \\
20\end{array}$ & $\begin{array}{l}0.78^{* *} \\
0.87^{* *} \\
0.80^{* *}\end{array}$ & $\begin{array}{l}0.8 \\
1.5 \\
1.8\end{array}$ \\
\hline \multirow{6}{*}{ 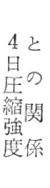 } & $G_{\max }$ & 0.110 & $0.520^{* *}$ & 1.400 & \multirow{2}{*}{$\begin{array}{c}6 \text { 䎸因の時の } \\
\text { 重相関係数 } \\
0.87^{* *}\end{array}$} & & & \\
\hline & $F M$ & $0.272^{* *}$ & $0.383^{* *}$ & 33.800 & & & & \\
\hline & $s / a$ & $-0.565^{* *}$ & $-0.590^{* *}$ & -3.810 & \multirow{2}{*}{ 寄 $\frac{\text { 与 }}{0.75}$ 率 } & & & \\
\hline & $W$ & $-0.532^{* *}$ & 0.171 & 0.498 & & & & \\
\hline & $C$ & $0.564^{* *}$ & $0.770^{* *}$ & 1.270 & 回 㷌积养 & & & \\
\hline & $\xi$ & 0.094 & 0.084 & 0.232 & 24.00 & & & \\
\hline
\end{tabular}

表一6 充填率, 強度と配合要因との関係

**危険率 $1 \%$ で有意 * 同 $5 \%$ で有意 
(2) 充填率と砂の粗粒率, 粗骨材最大寸法, 細骨材 率, セメントペースト量との関係

同じ実験データから重回帰式を推定するとつぎのよう に表わされる。

$$
\xi=4.5 F M+0.07 G_{\max }-0.39 s / a+0.19 p+64 .
$$

この関係は, 重相関係数 0.74 , 回帰誤差 2.0 となって おり, $F M, G_{\max }, p$ が増すと $\xi$ は増し, $s / a$ が増すと $\xi$ は減る。要因として前節のように $C$ と $W$ をとっても, また $p$ とてとり上げてもほとんど同じ精度で $\xi$ を推定 できるようである。また $G_{\max }$ を省くと重相関係数 0.70 , 回帰誤差 2.1 であって, 要因から $G_{\max }$ を除いて もよいと考えられる。

(3) 充填率と全骨材量, 全骨材の粗粒率, 水セメント 比との関係

これらを要因として分析する時は, 重回帰式として次 式を推定しらる。

$$
\xi=-0.13 a+6.2 F M_{(A)}+4.6 W / C+171
$$

この関係では重相関係数 0.58 , 回帰誤差 2.2 となって おり, 要因の選び方としては, 他の場合にくらべて精度 が低いといえる。

(4) 条件の異なる場合の補正方法

以上のように考察してきた傾向を利用して, コンクリ 一トの配合設計をする際に, 条件が異なった場合には, 所定の充填率を得るようにほほぼ表一7のように補正を 行なえばよいといえる。

\section{表一7 条件の異なる場合の補正方法}

\begin{tabular}{l|c}
\hline 変わる条件 & 補 正 の 方 法 \\
\hline 粗骨材最大寸法 $\pm 10(\mathrm{~mm})$ & $W \mp 3\left(\mathrm{~kg} / \mathrm{m}^{3}\right)$, または $s / a \pm 2(\%)$ \\
\hline 砂の粗 粒率 \pm 0.1 & $W \mp 2\left(\mathrm{~kg} / \mathrm{m}^{3}\right)$ または $s / a \pm 1(\%)$ \\
\hline 細骨材率 $\pm 1 \quad(\%)$ & $W \pm 2\left(\mathrm{~kg} / \mathrm{m}^{3}\right)$ \\
\hline
\end{tabular}

\section{b）圧縮強度と各種要因との関係}

材令 4 日圧縮強度と, 粗骨材最大寸法, 砂の粗粒率, 細骨材率, 単位水量, 単位セメント量および充填率の関 係について調べた。これらの変数に関して重相関分析を 行なった結果は表一6に示した通りである。寄与率や相 関が高いので重回浠式を推定するとつぎのようになる。

$$
\begin{aligned}
\sigma_{4}= & 1.4 G_{\max }+33.8 F M-3.81 s / a+0.498 W \\
& +1.27 C+0.232 \xi-181
\end{aligned}
$$

寸なわち, $G, F M, W, C, \xi$ が増すと $\sigma_{4}$ は増し, $s / a$ が 増すと $\sigma_{4}$ は減ることがわかる。

強度と水量だけの単相関関係，すなわち，その側面の 関係のみをみる時は, 水量は減らす方が強度が大となる 関係を得ているが，他の要因が組み合わさった場 合に は，水量は多い方が強度は大きくなる傾向にあること が, 偏相関係数や偏回帰係数から考えられる。

以上のような関係から，コンクリートの配合の設計に 際しては, 強度上からは粗骨材は大きく, 砂の粗粒率も
大きく，細骨材率はできるだけ小さく選び，水は脱型後 に変型しない範囲で大きくとり, セメント量は多いほど 圧縮強度の大きい製品を得ることができることがわかっ た。

\section{（3）砕石を使用する場合}

砕石を使用する場合の実験 i ), すなわち所定の配 合 のコンクリートに振動する時間を変えて, 充填率を測定 した結果は図-4に示すように同じ配合の場合には，砕 石の場合の方が砂利の場合よりもやや詰まりにくい。振 動時間が長くなるほど充填率は増加し, 砕石の場合には 振動時間を 6 分間程度にすると, 砂利の場合の約 2 分間 の振動を加えたことに相当する。すなわち, 砕石の場合 には砂利の場合より振動時間を延長することによって， 充填率を砂利程度にすることもできると考えられる。

つぎに実験 ii）のように, 配合条件を変えた場合の実 験結果は表一8 に示す通りである。すなわち, 配合と成 形条件が同じ場合には, 充填率は砕石の方がやや低い。 また強度は砕石の場合の方が約 10〜20\%大きい。製品 の表面の仕上りの状態は, 硗石の場合には細骨材率が 25 \%では外観があらあらしく，少なくとも $30 \%$ 以上が望

\begin{tabular}{|c|c|c|c|c|c|c|c|c|c|}
\hline \multirow{2}{*}{$\begin{array}{l}\text { 砂の } \\
F M\end{array}$} & \multirow{2}{*}{$\begin{array}{l}s / a \\
(\%)\end{array}$} & \multirow{2}{*}{$\begin{array}{r}W \\
(\mathrm{~kg} / \\
\left.\mathrm{m}^{3}\right)\end{array}$} & \multirow{2}{*}{$\begin{array}{c}C \\
(\mathrm{~kg} / \\
\left.\mathrm{m}^{3}\right)\end{array}$} & \multicolumn{2}{|c|}{ 充填率 $\xi(\%)$} & \multicolumn{2}{|c|}{$\begin{array}{c}4 \text { 日強度 } \\
\sigma_{4}\left(\mathrm{~kg} / \mathrm{cm}^{2}\right)\end{array}$} & \multirow{2}{*}{\begin{tabular}{|c|}
$\xi$ 研石 \\
$\xi$ 砂利 \\
$\times 100$ \\
$(\%)$ \\
$(\%)$
\end{tabular}} & \multirow{2}{*}{$\begin{array}{c}\sigma_{4} \frac{\text { 碎石 }}{\sigma_{4} \text { 砂利 }} \\
\times 100 \\
(\%) \\
(\%)\end{array}$} \\
\hline & & & & 砂利 & 确石 & 砂利 & 砕石 & & \\
\hline \multirow{7}{*}{2.00} & \multirow{2}{*}{25} & 90 & 200 & 99 & 92 & 172 & 129 & 93 & 75 \\
\hline & & 110 & 200 & 94 & 100 & 127 & 158 & 106 & 124 \\
\hline & \multirow{3}{*}{30} & 105 & 200 & 100 & 100 & 152 & 164 & $\cdot 100$ & 108 \\
\hline & & 115 & 200 & 100 & 100 & 145 & 158 & 100 & 109 \\
\hline & & 105 & 220 & 99 & 98 & 179 & 192 & 99 & 107 \\
\hline & \multirow{2}{*}{40} & 130 & 200 & 99 & 98 & 83 & 118 & 99 & 142 \\
\hline & & 130 & 220 & 97 & 99 & 129 & 134 & 102 & 104 \\
\hline \multirow{5}{*}{2.75} & \multirow{2}{*}{30} & 95 & 200 & 100 & 98 & 185 & 202 & 98 & 109 \\
\hline & & 95 & 220 & 100 & 100 & 210 & 228 & 100 & 109 \\
\hline & \multirow{2}{*}{40} & 115 & 200 & 99 & 100 & 103 & 177 & 101 & 172 \\
\hline & & 115 & 220 & 100 & 100 & 170 & 195 & 100 & 115 \\
\hline & 50 & 130 & 200 & 99 & 98 & 96 & 132 & 99 & 138 \\
\hline
\end{tabular}

\section{図一4振動時間と充填率の関係}

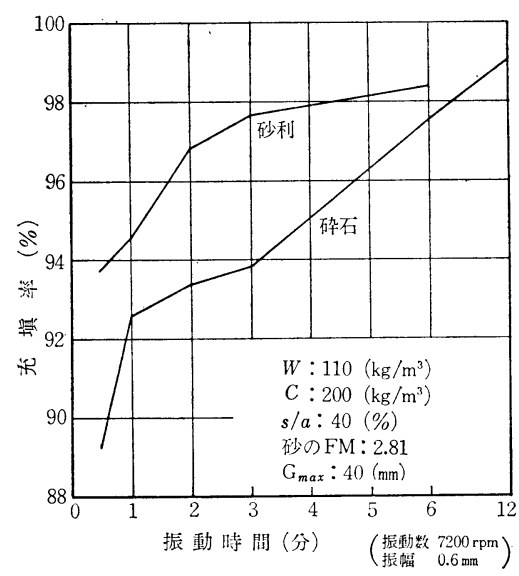

表一8 砕石と砂利の比較 
ましい。一般には砂利の場合よりも, 細骨材率を $5 \%$ 程 度増した方がよい。砕石の場合には, 砂利の場合よりも 空げきが多いので, これを充填する意味でも, 砂利の場 合よりもモルタル量が多く必要なことが考えられる。ま た砕石を使用する場合の超硬練りコンクリートの練りま ぜは，骨材の周囲に付着するペーストやモルタルが多 く，造粒して丸くなるような傾向を生じがちで，しかも 他の部分と分離しやすいので注意を要する。

\section{（4）混和剂の影響}

材料混合の方法, 配合の種類, 混和剤の種類による効 果を, 試験条件にしたがって, ランダムな順序で実験を 行ない,コンクリートの充填率および材令 3 日強度を測 定した。結果は表一9に示す通りである。

\section{表一9 混和剤の効果に関する実験結果}

\begin{tabular}{|c|c|c|c|c|c|c|c|c|c|}
\hline \multirow{2}{*}{$\begin{array}{l}\text { 練り } \\
\text { ませ } \\
\text { 方法 }\end{array}$} & \multirow{2}{*}{ 混和剂 } & \multirow{2}{*}{$\begin{array}{l}s / a \\
(\%)\end{array}$} & \multirow{2}{*}{$\begin{array}{l}W / C \\
(\%) \\
\end{array}$} & \multicolumn{4}{|c|}{ 単 位量 $\left(\mathrm{kg} / \mathrm{m}^{3}\right)$} & \multirow{2}{*}{$\begin{array}{c}\text { 充填率 } \\
\xi \\
(\%) \\
(\%)\end{array}$} & \multirow{2}{*}{$\begin{array}{c}3 \text { 日強度 } \\
\sigma_{3} \\
\left(\mathrm{~kg} / \mathrm{cm}^{2}\right)\end{array}$} \\
\hline & & & & $W$ & $C$ & $S$ & $G$ & & \\
\hline \multirow{6}{*}{ A } & プレーン & 40 & 55 & 110 & 200 & 848 & 1324 & 100 & 122 \\
\hline & $\mathrm{P}$ & 40 & 55 & 110 & 200 & 848 & 1324 & 100 & 148 \\
\hline & $\mathrm{V}$ & 40 & 55 & 110 & 200 & 848 & 1324 & 98 & 111 \\
\hline & プレー & 40 & 40 & 100 & 250 & 840 & 1315 & 99 & 163 \\
\hline & $\mathrm{P}$ & 40 & 40 & 100 & 250 & 840 & 1315 & 99 & 181 \\
\hline & V & 40 & 40 & 100 & 250 & 840 & 1315 & 97 & 150 \\
\hline \multirow{6}{*}{ B } & プレー & 40 & 55 & 110 & 200 & 848 & 1324 & 99 & 94 \\
\hline & $\mathrm{P}$ & 40 & 55 & 110 & 200 & 848 & 1324 & 99 & 127 \\
\hline & $\mathrm{V}$ & 40 & 55 & 110 & 200 & 848 & 1324 & 98 & 101 \\
\hline & プレーン & 40 & 40 & 100 & 250 & 840 & 1315 & 96 & 95 \\
\hline & $\mathrm{P}$ & 40 & 40 & 100 & 250 & 840 & 1315 & 98 & 159 \\
\hline & V & 40 & 40 & 100 & 250 & 840 & 1315 & 97 & 119 \\
\hline
\end{tabular}

a）充填率におよぼす影響

実験結果の充填率について 分散分析の 結果は 表一10 の通りである。

混合方法, 配合の種類, 混和剂の種類のどの要因も著 しく有意と判定される。

混合方法では， $\mathrm{A}_{1}$ 方法が充填率が大となるといえる。 配合の種類では， $\mathrm{B}_{1}$ 配合の方が充填性がよい。

混和剤の種類では, プレーンの場合にくらべて, 分散 剂を使った場合には充填率が増し， $\mathrm{AE}$ 剂使用の場合に は， $\mathrm{A}_{1}$ では充填率は小さくなり， $\mathrm{A}_{2}$ ではやや大きくな っている。Aと B，AとCの間には交互作用があると判 定される。

以上のことから，充填率を増すために混和剤を使用す

表-10 分散分析表（充填率について）

\begin{tabular}{|c|c|c|c|c|c|c|}
\hline 因 & 平方和 & 自由度 & 不偏分散 & 分散比 & $\begin{array}{c}F \\
(0.01)\end{array}$ & $\begin{array}{c}F \\
(0.05)\end{array}$ \\
\hline 混合方法 (A) & 5320 & 1 & 5320 & $17.80^{* *}$ & 8.53 & \\
\hline 配 合 (B) & 17510 & 1 & 17510 & $57.50^{* *}$ & 8.53 & \\
\hline 混和 剂 (C) & 9443 & 2 & 4722 & $15.50^{* *}$ & 6.23 & \\
\hline$A \times B$ & 2734 & 1 & 2734 & $8.97^{* *}$ & 8.53 & \\
\hline$A \times C$ & 2543 & 2 & 1272 & $4.19^{*}$ & & 3.63 \\
\hline 誤差 & 4868 & 16 & 304 & & & \\
\hline 計 & 42418 & 23 & & & & \\
\hline
\end{tabular}

るには，練りまぜの際には全材料を同時に混合して用い る方法がよく, 混和剤としては $\mathrm{AE}$ 剂より分散剤を選ぶ のが効果的であるといえる。

b）強度におよぼす影響

材令 3 日圧縮強度についての分散分析の結果は表一11 の通りである。

\section{表一11 分散分析表（強度について）}

\begin{tabular}{|c|c|c|c|c|c|c|}
\hline 因 & 平方和 & 自由度 & 不偏分散 & 分 散 比 & $\begin{array}{c}F \\
(0.01)\end{array}$ & $\begin{array}{c}F \\
(0.05)\end{array}$ \\
\hline 混合方法 (A) & 5612 & 1 & 5612 & $65.84^{* *}$ & 8.53 & \\
\hline 配 合 (B) & 3775 & 1 & 3775 & $44.29^{* *}$ & 8.53 & \\
\hline 混 和 剂 (C) & 7081 & 2 & 3541 & $41.54^{* *}$ & 6.23 & \\
\hline$A \times B$ & 950 & 1 & 950 & $11.15^{* *}$ & 8.53 & \\
\hline$A \times C$ & 920 & 2 & 460 & $5.40^{*}$ & & 3.63 \\
\hline 詥 差 & 1364 & 16 & 85 & & & \\
\hline 計 & 19702 & 23 & & & & \\
\hline
\end{tabular}

表一12 混合方法の効果 (\%) 混合方法, 配合種類およ

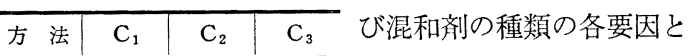
\begin{tabular}{l|l|l|l|l}
$\mathrm{A}_{1}$ & 100 & 100 & 100 & も著しく有意であると判定
\end{tabular}

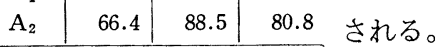

\section{表一13 配合の影響 (\%)}

\begin{tabular}{c|c|c|c}
\hline 配 合 & $\mathrm{C}_{1}$ & $\mathrm{C}_{2}$ & $\mathrm{C}_{3}$ \\
\hline $\mathrm{B}_{1}$ & 100 & 100 & 100 \\
$\mathrm{~B}_{2}$ & 119 & 124 & 123 \\
\hline
\end{tabular}

表一14 混和剤の効果 $(\%)$

\begin{tabular}{c|c|c|c}
\hline 方法 & $\mathrm{C}_{1}$ & \multicolumn{1}{c|}{$\mathrm{C}_{2}$} & \multicolumn{1}{c}{$\mathrm{C}_{3}$} \\
\hline $\mathrm{A}_{1}$ & 100 & 115.5 & 91.9 \\
$\mathrm{~A}_{2}$ & 100 & 154 & 112 \\
\hline
\end{tabular}

は，表一14 に示す通りで，分散剂はプレーンの場合に 対して, どちらの混合方法の場合にも強度は大きくなっ ている。 $\mathrm{AE}$ 剂の時には, $\mathrm{A}_{1}$ 方法では強度が低下し, $\mathrm{A}_{2}$ 方法では増加している。また強度に対しては， $\mathrm{AE}$ 剂を使用するよりも分散剂を使用する方が効果的である ことが 表一14 から判定される。

$\mathrm{A}$ と B，AとCの間には交互作用がある。

以上の結果から，貧配合超硬練りコンクリートの振動 締め固めをする際に混和剤を選ぶには, 充填率と強度の 点からは, $\mathrm{AE}$ 剂よりも分散剂の方が有効と考えられ る。なお混合方法は, 各材料を全部同時に混合する方法 がよく，配合によっても影響を受けることがわかった。

\section{（5）長期強度の発現性}

実験の結果は 表一15 に示す通りである。材令 3 日か ら91 日まで, セメント水比と圧縮強度の関係は直線的 に変化して, 相関が大きいことが認められ，セメント水 比が大きくなると強度も大きくなる（図一5)。

比較のために行なった，プラスチックでワーカブルな スランプ $7.5 \mathrm{~cm}$ のコンクリートの場合にくらべると， 振動締め固めをしたコンクリートの材令 28 日圧縮強度 
表-15 長期強度試験 結果

\begin{tabular}{|c|c|c|c|c|c|c|c|c|c|c|c|}
\hline \multirow{2}{*}{$\begin{array}{l}\text { 混 } \\
\text { 秚 } \\
\text { 剂 }\end{array}$} & \multirow{2}{*}{$\begin{array}{l}W / C \\
(\%)\end{array}$} & \multirow{2}{*}{$\begin{array}{l}s / a \\
(\%)\end{array}$} & \multirow{2}{*}{$\begin{array}{c}W \\
\left(\mathrm{~kg} / \mathrm{m}^{3}\right)\end{array}$} & \multirow{2}{*}{$\begin{array}{c}C \\
\left(\mathrm{~kg} / \mathrm{m}^{3}\right) \\
\end{array}$} & \multirow{2}{*}{$\begin{array}{c}\text { 充 填 率 } \\
\text { の平均值 } \\
(\%)\end{array}$} & \multicolumn{4}{|c|}{ 圧 縮 強 度 $\left(\mathrm{kg} / \mathrm{cm}^{2}\right)$} & \multicolumn{2}{|c|}{ 強度の伸び率 } \\
\hline & & & & & & 3 日 & 7 日 & 28 日 & 91 日 & $\sigma_{3} / \sigma_{28}$ & $\sigma_{91} / \sigma_{28}$ \\
\hline \multirow{3}{*}{ な } & 61.2 & 40 & 110 & 180 & 98 & 109 & 151 & 248 & 289 & 0.44 & 1.17 \\
\hline & 55.0 & 40 & 110 & 200 & 100 & 145 & 215 & 343 & 378 & 0.43 & 1.10 \\
\hline & 48.9 & 40 & 110 & 225 & 100 & 157 & 225 & 340 & 415 & 0.46 & 1.22 \\
\hline 2 & 42.0 & 40 & 105 & 250 & 99 & 210 & 276 & 435 & 496 & 0.48 & 1.14 \\
\hline \multirow{3}{*}{$\begin{array}{l}\text { 分 } \\
\text { 散 } \\
\text { 諭 } \\
(\mathrm{P})\end{array}$} & 55.0 & 40 & 110 & 200 & 100 & 114 & 212 & 376 & 462 & 0.30 & 1.23 \\
\hline & 48.9 & 40 & 110 & 225 & 100 & 143 & 231 & 421 & 472 & 0.34 & 1.12 \\
\hline & 42.0 & 40 & 105 & 250 & 99 & 180 & 292 & 501 & 544 & 0.36 & 1.09 \\
\hline \multirow{3}{*}{$\underset{\text { 剂 }}{\mathrm{A}}$} & 55.0 & 40 & 110 & 200 & 100 & 107 & 201 & 353 & 487 & 0.30 & 1.38 \\
\hline & 48.9 & 40 & 110 & 225 & 100 & 138 & 222 & 373 & 443 & 0.37 & 1.19 \\
\hline & 42.0 & 40 & 105 & 250 & 99 & 171 & 278 & 456 & 496 & 0.37 & 1.09 \\
\hline
\end{tabular}

\section{5. むす び}

振動締め固めをする超硬ねり 貧配合コンクリートの配合設計 の方針をまとめると，つぎのよ らにいえよう。ただし，標準の 配合に使用する砂利および砂の 粒度は, 土木学会コンクリート 標準示方書に示された標準粒度 範囲のほぼ中央に入るものとす る。砂の粗粒率は 2.75 である。 コンクリートのセメント量

は，同じセメント 水比の時でも大き い強度を得る傾向 があることがわか る。すなわち，普 通コンクリートに くらべると, 強度 については, 単位 セメント量は使用 する単位水量が少 ないために，同じ セメント水比では 単位セメント量を 少なくしうるが,
図一5 セメント水比と圧縮強度と の関係

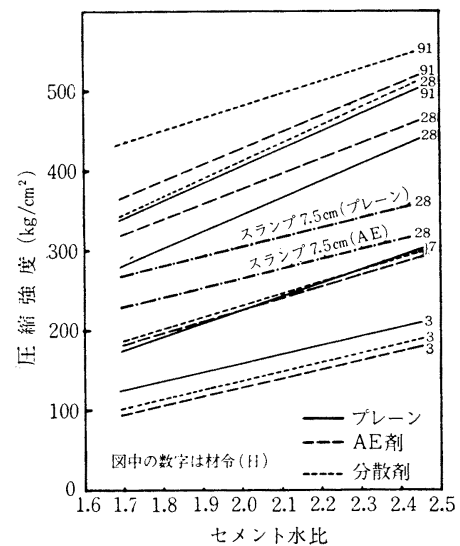

それ以上に少ないセメント量で所要強度をうるようにコ ンクリートの配合設計をしうると考えられる。また，分 散剤， $\mathrm{AE}$ 剂を用いた場合には充填率はほとんど変わら ないが，強度では図一5に示したように，材令 3 日では プレーンコンクリートが最も強度は大きく, 分散剤, $\mathrm{AE}$ 剤の順に強度は小さくなっている。材令 7 日になると， いずれもほとんど同程度の強度を示している。材令 28 日以降になると，強度は分散剤を使ったものが最も大き くなる。水セメント比 $50 \%$ 付近では，材令 28 日強度は 分散剤ではプレーンの場合の約 19\% 増し, $\mathrm{AE}$ 剤では 約 16\% 増しとなっている。

長期強度については材令 28 日から 91 日にわたって約 $10 \%$ 以上の伸びが期待される。

以上のことから，超硬練り貧配合の振動締め固めをし たコンクリートの強度はセメント水比との関係から設計 することができ, 材令 28 日強度は次式から推定するこ とができる。

プレーンの場合 $\quad \sigma_{28}=215 C / W-83$

分散剂使用の場合 $\sigma_{28}=223 C / W-32$

$\mathrm{AE}$ 剂使用の場合 $\quad \sigma_{28}=188 C / W+3$

混和剤の種類としては, 強度に対しては分散剤の使用 が効果的であると考えられる。
は, この実験から, 製品運搬時の初期強度, あるいは材 令 28 日強度などから求められるが，コンクリート表面 の仕上り状況から, 単位セメント量としては $200 \mathrm{~kg} / \mathrm{m}^{3}$ 以上が望ましい。つぎに水量は，表一16 に示す值を目

表一16 基準配合表（砂の $F M=2.75 ）$

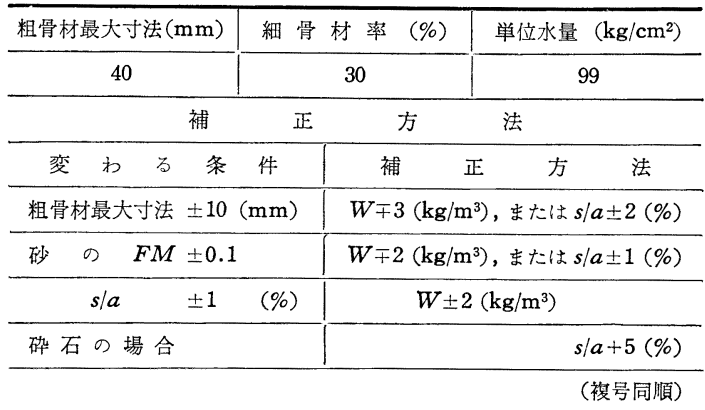

標とすると便利であろう。この水量は，多くの実験の結 果に基づくものであって，粒形などが良好な骨材の場合 であるから，実際の場合には条件が異なるので，その時 は表中の補正を行なえばよい。ただし，水量は普通コン クリートの場合と異なって，即時脱型した時に変形しな 、範囲で多くする方が充填性もよく，強度も大となる傾 向がある。細骨材率の決定には，それぞれ使用する骨材 の性状にしたがって調整しなければならないが，実験結 果から充填性および圧縮強度に対しては，モルタル量と して不足することのないこと，および十分に振動締め固 めのできる範囲で，細骨材率は小さく選ぶのがよい。な 抒振動締め固めをする場合には，混和剤は充填率，強度 などの点から $\mathrm{AE}$ 鼡よりも分散剤の方が有効であること がわかった。

\section{参 考 文 献}

1) S.G. Bergstrom : Laboratory test on Vibration of Concrete, Jour. ACI, Vol. 49, pp. 893 908, June 1953.

2) A.R. Cusens : The influence of amplitude and frequency in the compaction of concrete by table vibration, Magazine of Concrete Research, Vol. 10, No. 29, pp. 79 86, Aug. 1958.

3) G. Brush : Ein Untersuchung von Rüttelbeton, Zement, p. 16, Juni 1938.

4) $\mathrm{ACI}$ Committee 609 : Consoidation of Concrete, Jour. 
ACI, Vol. 56, pp. 985 1012, Apr. 1960.

5）山田順治 : 第 4 回 国際コンクリート製品工業会議に出席 して, セメントコンクリート, No. 202, pp. 9〜19, 1963 年 12 月.

6) G.W. Washa : Vibration Practice in Pipe, Precast and Block Manufacture, Jour. ACI, Vol. 49, pp. 945 952, June 1953.

7) H. Green : Compaction of Mortar and Concrete by vibration, Civil Engineering and Public Works Review, Vol. 57, No. 669, pp. 467 469, Apr. 1962; Vol.57, No. 670, pp. 632 634, May 1962.

8) 内山 実: カタ練りコンクリートの経済的配合の設計, 土木学会誌, 35-4, pp. 6 11, 1950 年 4 月.

9）石橋 実・四戸英男 - 有川 晋 : 機械振動詰 即時脱型様 式に使用する超硬練コンクリートの調合設計， 日本建築
学会論文集, 57, pp. 121 124, 1957 年 7 月.

10) P. Kreman : Vibrationstechnik bei der maschinellen verdichtung von Frischbeton, Betonstein-Zeitung, Heft 4, pp. 186 191, Apr. 1963.

11) ACI Committee 211 : Recommended Practice for Selecting Proportions for No-Slump Concrete, Jour. ACI, Vol. 62, pp. 1 21, Jan. 1965.

12）山本 実・相沢䉓之助・伊福部宗夫：超硬練コンクリー トブロックの強度について, 土木学会北海道支部技術資 料, 22 , pp. $69 \sim 82,1966$ 年 2 月.

13）たとえば, 佐藤良一郎 : 数理統計学概説, 初版, 培風館, 1951 年.

14）萩原尊礼：振動測定，5版，宝文館，1957 年.

(1968. 3. 15. 受付) 